and speculative discussion which tends to surround the "beta blockade withdrawal syndrome", confining our conclusions to the specific agent and clinical setting tested. If it can ever be considered reasonable to withdraw a beta blocker then based on our data in patients with severe stable angina it should surely not be considered a "dangerous" practice to stop treatment with atenolol in patients who have mild or no symptoms?

P R Walker, Department of Cardiology, Bristol Royal Infirmary, Bristol BS2 8HW.

\section{References}

1 Meinertz T, Just H, Kasper W, Kersting F, Breuing
K-H. $\beta$-blocker withdrawal syndrome? Lancet 1979; i: 270.

2 Alderman EL, Coltart DJ, Wettach GE, Harrison DC. Coronary artery syndromes after sudden propranolol withdrawal. Ann Intern Med 1974; 81: 625-7.

3 Diaz RG, Somberg JC, Freeman E, Levitt B. Withdrawal of propranolol and myocardial infarction [Letter]. Lancet 1973; i: 1068.

4 Slome R. Withdrawal of propranolol and myocardial infarction [Letter]. Lancet 1973; i: 156.

5 Mizgala HF, Counsell J. Acute coronary syndromes following abrupt cessation of oral propranolol therapy. Can Med Assoc F 1976; 114: 1123-6.

6 Nattel S, Rangno RE, Loon GV. Mechanism of propranolol withdrawal phenomena. Circulation 1976; 59: 1158-64.

7 Ross PJ, Lewis MJ, Sheridan DJ, Henderson AH. Adrenergic hypersensitivity after beta-blocker withdrawal. Br Heart f 1981; 45: 637-42.

8 Shand DG, Wood AJJ. Propranolol withdrawal syndrome-why? Circulation 1978; 58: 202-3.

\title{
Effect of timolol on changes in serum potassium concentration during acute myocardial infarction
}

Sir,

Nordrehaug et al (1985; 53: 388-93) showed that the administration of timolol after myocardial infarction reduces the frequency of hypokalaemia during the first 24 hours after the infarct. For greater accuracy they should have used plasma rather than serum because there is erratic leakage from erythrocytes during coagulation.

Using insulin-induced hypoglycaemia (in healthy volunteers) as another model for acute stress, we have also observed that prior non-specific beta blockade with nadolol or propranolol prevents hypokalaemia. ${ }^{12}$ Since these effects of stress are mediated through a pronounced increase in plasma catecholamine concentrations it is pertinent to mention that adrenaline-induced influx of potassium into leucocytes in vitro is inhibited by the nonselective beta blocker, timolol and that these cells are probably a model for body cells as a whole. ${ }^{3}$ In addition, beta blockade in the hypoglycaemia model $^{1}$ reduces the magnitude of $(a)$ increase in serum free fatty acid concentrations by inhibiting lipolysis; $(b)$ the increase in various haemostatic variables like factor VIII related antigen; (c) platelet aggregation. These effects are related to the pathogenesis of myocardial infarction since they are all arrhythmogenic or prothrombotic. ${ }^{4-6}$ It is also important to determine whether selective blockade of beta ${ }_{1}$ receptors produces similar results since some of the above effects of catecholamines are thought to be mainly mediated by beta ${ }_{2}$ receptors.

\author{
D P Mikhailidis, \\ P Dandona, \\ D N Baron, \\ Department of Chemical Pathology and Human \\ Metabolism, \\ Royal Free Hospital and School of Medicine, \\ London NW3 2QG.
}

\section{References}

1 Mikhailidis DP, Barradas MA, Hutton RA, Jeremy JY, Sabur M, Dandona $P$. The effect of non-specific $\beta$-blockade on metabolic and haemostatic variables during hypoglycaemia. Diabetes Research 1985; 2: 127-34.

2 Mikhailidis DP, Dandona P. Adrenaline and potassium. Lancet 1984; i: 170.

3 Baron DN, Green RJ, Khan FA. Adrenaline and ion flux in isolated human leucocytes. Clin Sci 1985; 68: 517-21.

4 Tansey MJB, Opie LH. Relation between plasma free fatty acids and arrhythmias within the first twelve hours of acute myocardial infarction. Lancet 1983; ii: 419-22.

5 Jeremy JY, Mikhailidis DP, Dandona P. Simulating the diabetic environment modifies in vitro prostacyclin synthesis. Diabetes 1983; 32: 217-21.

6 Mikhailidis DP, Mikhailidis AM, Barradas MA, Dandona P. Effect of non-esterified fatty acids on the stability of prostacyclin activity. Metabolism 1983; 32: $717-21$. 